\title{
Marketing and Progress of Dairy Development in Uttar Pradesh: A Comparative Study of Two Regions
}

\author{
Nizamuddin Khan ${ }^{1} \quad$ Mohd. Azhar ${ }^{2} \quad$ Ashish Kumar Parashari ${ }^{3}$ \\ Department of Geography, A.M.U. Aligarh \\ 1 Professor (Department of Geography, AMU) \\ 2 Professor in Economics (Department of West Asian Studies, AMU) \\ 3 Research Assistant (Department of Geography, AMU)
}

\begin{abstract}
Marketing refers the process of creating demand, value addition, transportation and distribution for performing the function of place, time and form utility of any product on the space. The improvement in dairy product market through an efficient marketing chains with refrigerated transport and storage as well as with expansion in number and size and scale of economy created a revolution in dairy sector in the country and in the state of Uttar Pradesh .AMUL, PARAG, MOTHER DAIRY, NANDINI from cooperative sector and several private companies played significant role in marketing and processing of dairy products but still their shares do not exceed one third of marketed surplus of raw milk and milk products. Unorganised sector showed domination due to small size of marketable, perishability of products, need for cash payment and tendency of dairy farmers for selling adulterated milk .Uttar Pradesh is the leading producer and largest markets for dairy products in response to increasing urbanization, enhancing disposable income, domination of vegetarian food choices and increasing awareness for nutrition rich food for good health. Regional variation in milk production, processing and marketing infrastructure development is common. The comparison of two districts from developed and nondeveloped areas are testimonial to such inter district / regional imbalance in dairy development despite continuous effort of both central and state government since independence. Dairy farm production systems are treasure of tremendous opportunities for farmers and area development. Development of fodder production farms, outlet establishment for supply of concentrates, production and supply of feed grains, new development of credit and insurance institutes and investment in local dairy processing industries are some valuable opportunities in dairy farm production. The plan of doubling farmer's income and strengthen the level of economic self-reliance in rural area could be achieved successfully.
\end{abstract}

Keywords: Dairy, Cold Chain, Milk Processing, marketing

DOI: $10.7176 / \mathrm{JESD} / 11-22-08$

Publication date: November $30^{\text {th }} 2020$

\section{Introduction}

Marketing refers the process of creating demand, value addition, transportation and distribution for performing the function of place, time and form utility of any product on the space. Agricultural marketing is a process which starts with the decision to produce a saleable farm commodity, and it involves all the aspects of market structure or system both functional and institutional, , based on technical and economic considerations, and includes pre and post-harvest operations, assembling, grading, storage, transportation and distribution[1]. Similarly, being perishable nature of milk like several other agricultural products, the transaction and distribution of dairy and dairy products is very complex socio economic phenomena. Dairying is not only an economic entity but social and cultural mechanism interwoven in economic fabrics. Dairy marketing could be understood in an integrated framework of farmers production, processing modules and system, structure and composition of consumers and nature and strength of demand in response to purchasing power, health consciousness for nutrition intake, level of living standard and food habits, capital investment, both from public and private sector, markets structure and linkage from farm gate to global markets. Demand pattern, a dynamic and income, taste, ethics, quality as well as degree of accessibility elastic phenomena, transmits the signal for enhancement and reduction in production at farmer's level. Marketing of agricultural products especially dairy and dairy derived products plays dual role in economic development in agrarian economy, firstly, generate demand for milk and rise farmer's income and purchasing power and secondly, off dairy activities / products as well non-farm products multiplied in retrospect to first, resulting over all rural development of concerned area. An efficient market which ensures fair participation and price of farmers in products transaction, protect the rational benefit of intermediaries and reasonable price to consumers. Optimization of resource use and output management, increase in milk production, widening of markets, and growth of milk based processing industries, technological innovation and adoption, employment generation, poverty alleviation, improvement in national income and improvement in living standards are important results of an efficient and competitive dairy marketing system[2].

India is the largest producer as well as has largest consumers of milk in world, accounting for 19 percent 
of global market share in dairy and dairy product business in 2018[3]. The market, consisting both national and international players, is expected to expand and getting strength in future owing to increasing demand for value added dairy products in national markets especially among urban consumers and in international markets due to competitive advantage for low production cost and market price as compared to developed world in dairy production. Products of added value are considered as additional services to the core value of a product, which are "both relevant and welcomed by customers[4]. This gives consumers an additional value and attraction to pay extra price up to the level which they perceive it valuable to pay extra amount[5]. Product differentiation, nich marketing, branding, packaging, advertisement and research and development innovation are important strategies to make product value added[6] [7] [8]. Marketing is a pull strategy to make attractive the commodities through processing in different ways to serve specific need or want of consumers.

India currently represents the world's biggest market for milk and milk products. In light of its growing population, higher incomes and growing health consciousness, the demand for milk is steadily increasing in the country [9]. The dairy markets in the country is dominated by unorganised sector including producer sellers, village traders, processing units of small scale following traditional techniques with cheap, low grade, unhygienic products[10]. This reduces overall quality and nutrition level of milk produced. India produced 400 million litres per day milk and 160 million litres(48\%) is consumed by producers themselves, 240 million litres is marketable surplus, out of which only 70 million litres used by organised sectors i.e. Amul, Mother Dairy and Nandini under cooperative groups and private sector companies i.e. Nestle, Dennone, Hatsun, Heritage food and Parag[11]. The liberalization of agri-business opened the door for foreign direct investment in dairy sector after establishment of WTO in 1994 [12] [13]. Several foreign companies as discussed above I,e, Dennone, Nestle, Graupe Lactailis SA,are important players in Indian dairy market[14]. Study revealed that the performance of these international players is not appreciable because they are failed to compete with Indian consumers and processing units[15]. Traditional retails picked up a lion share in dairy market. It accounts for INR 5 trillion, out of INR 6 trillion of Indian dairy markets in 2019. Indian Council of Food \&Agriculture (ICFA) presented report on Indian Dairy Product Markets, which reflected the fact that despite being largest producer of milk, the export has been consistently declining from $1.08 \%$ of world dairy trade in 2013 to $0.13 \%$ in 2019 and import improved from $0.53 \%$ to $0.55 \%$ during same period as the dairy industries customers to face challenge from lack of quality and low productivity as a result of large part of market is unorganised[16].Moreover, the country's share in production increased consistency from $17.40 \%$ to $20.64 \%$ during 2010 to 2018 while the consumption registered share change from $18.85 \%$ to $22.99 \%$ during same period. The report also reflected the scenario of dairy product production and consumption during aforesaid interval. The consumption level is rather low during this period than the production. Production rose up from 203.80 million tonnes in 2010 to 279.42 million tonnes in 2018 with a tune of $37 \%$ growth rate whereas the consumption level of dairy products changed from 82.05 to 115.42 million tonnes at a rate of $40.67 \%$ during same period. NITI Ayog working group report viewed that demand of milk in the country has been surpassed by supply since 1990's and projected supply of milk with 289.00 million tonnes and demand of 256 million tonnes during 2029-30 against 194 million tonnes and 174 million tonnes during 2020-21 supply and demand respectively[17]. India has potential to export dairy products but it is very slow due to domination of unorganised traditional sector with low quality goods, less attractive to international consumers. World dairy products exporting countries like USA, Australia, New Zealand, European countries are looking India as one of the potential markets for trade of dairy products. The Indian experts and agricultural and social economists opined that the penetration of imported dairy products will affect negative to Indian dairy farming and marketing system as country has already extra marketable surplus[18].

The government of India has been continuously making efforts for achieving supremacy in dairy sector with a view to enhance availability and accessibility of milk to her population, maintain nutrition security, increase employment and income and developing sustainability of agriculture and farmers. National Programme for Dairy Development (NPDM) National Dairy Plan Phase I (NDPPI), Dairy Entrepreneurships development Scheme (DEDS), Dairy Processing and Infrastructure Development Fund(DPIDF) are important strategies and policies enacted for improvement of this sector of agriculture economy. Direct marketing, contract marketing, Cooperative marketing as well as channelled marketing of raw milk and dairy products are significant components of dairy economic sector in the country. National Action Plan for Dairy Development - Vision 2022, under the guidance of Department of Animal Husbandry, Dairying and Fisheries, Ministry of Animals and Farmers Welfare, Government of India, highlighted the market demand, caused by mainly population growth, urbanization, increasing income, changing food habits and life styles, increasing consumers interest in high protein diets and availability of dairy products through organized channels or food chain, is the main driver of upsurge in milk production and expansion, both vertical and horizontal, of dairy farming in rural India.

Dairy marketing and markets development is one of the pivotal strategies of shifting terms of trade in favour of agriculture of new agricultural policy enacted in India during July 2020.It is expected to rise the price of raw milk and processed products, which would result in scaling up, and industrialization of dairy sector through increasing capital investment in dairying operation, infrastructural facilities, both technical and 
institutional development in rural areas. The new emerging trend of dairy trade, intends to integrate dairy farmers at grassroots level with complex market channels of global, national as well as local nature with efficient and fast network of refrigerated storage, transportation, institution, technology and finally consumers. Doubling of farmers' income and development of self-sufficiency and reliance among rural masses under scheme of Atmanirbhar (self-reliance) mission of Government of India during COVID 19 period could be achieved. Moreover, the process of marketing and production and the degree of integration among different stakeholders are uniform all over the country but exhibiting regional and intra-regional variation in response to socio economic, ecological and demographic and political attributes of the area. It appears an essential and urgent need to understand marketing and distribution of milk and its derived products and their impacts on development of dairy farming at regional and local level for development an efficient and economically viable and producers and consumers favourable trade system in the country.

Moreover, country is moving towards shining Indian dairying through high capital investment in development of basic infrastructural facilities like link roads, assembling depots, chilling storage and transport; institutional facilities as veterinary hospitals, animal health care personnel at village panchayat level and EXIM facilities and incentive providing agencies at both at national and state level. The level of production and marketing of milk and milk products is unevenly developed in the country on account of variable geographical and ecological condition; nature of socio economic structure of producers and consumers and variation in level of urbanization, income, sex ratio, education as well as dominant species of milch animals. State and district level, comparative analysis of dairy farming, marketing, processing, production, consumption and development of allied activities, income and employment is an urgent call for formulation of strategies to achieve targeted development of dairy farming as means to doubling income of farmers and rural Atmanirbhar or self-reliance. The present study tries to find out status of marketing and production of dairy products in Uttar Pradesh and highlights comparative analysis of marketing and production of dairy and dairy products in two districts of Uttar Pradesh.

\section{Research Methodology}

The present work is based on secondary data published in different reports and existing published articles/ research papers. Primary data were also generated on different aspects like flow of milk and its derived products through various channels, nature and process of value addition, value added products, income and employment generation through dairy farming and its allied activities in two selected districts i.e. Bulandshahr and Balrampur from western and eastern Uttar Pradesh. The study follows two tier spatial structure. Uttar Pradesh is undertaken as macro region and all information's are derived from already published reports, research papers as well as official statistical documents. At second level, two districts representing high and low dairy developed area from U.P. are selected for comparative analysis to understand regional imbalance in dairy farming development. Figure 1 shows location of study area which highlights the relative positions of districts in Uttar Pradesh and in India. 


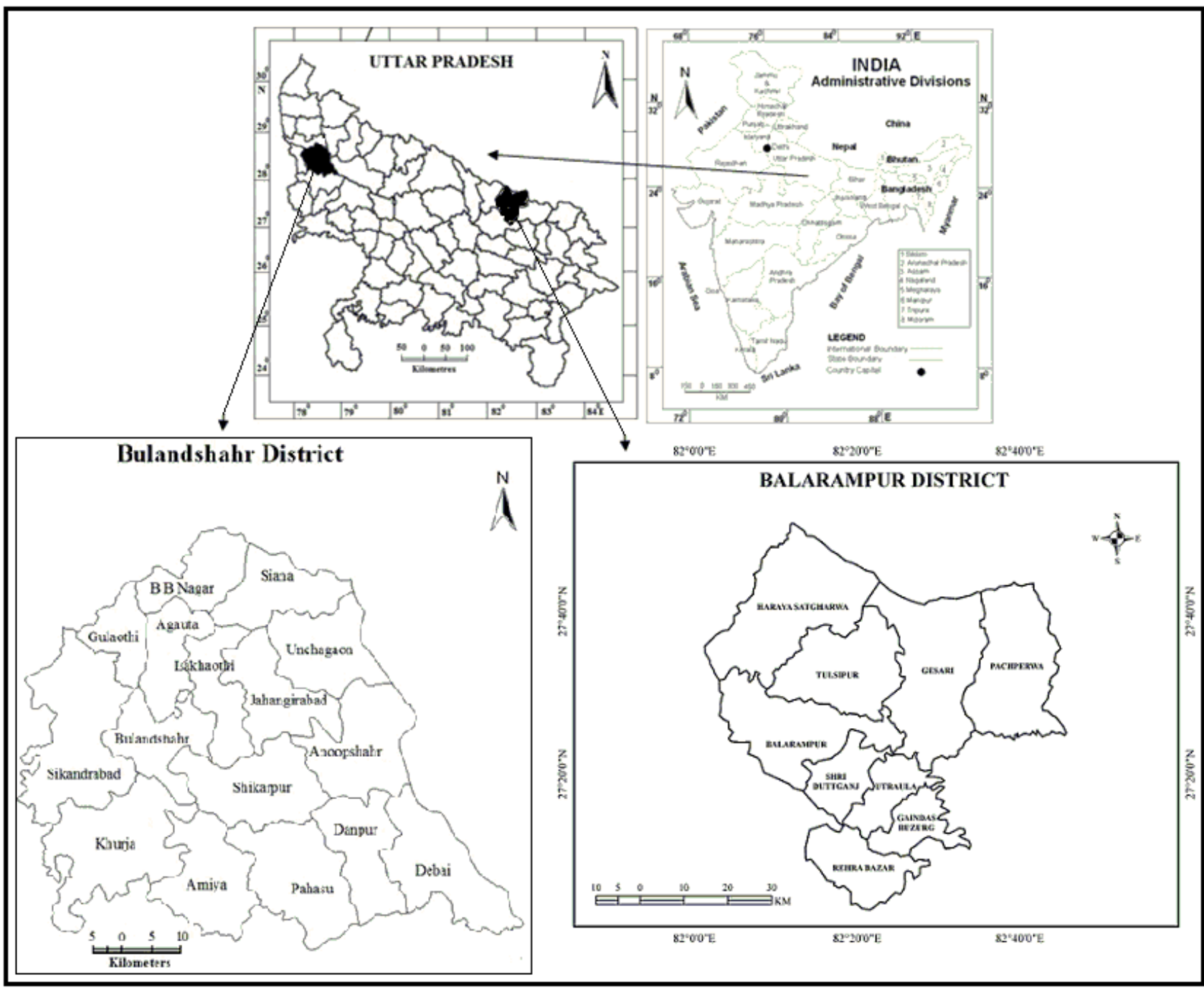

Fig. 1 Location of Study Areas

\section{Status of Uttar Pradesh in Dairy Farming}

Uttar Pradesh is the highest milk producing state of the country with production of 30.50 million tonnes (201819) of milk. The milk production and availability (grams) per head per day have been continuously increasing year after year during $21^{\text {st }}$ century in the state. Production surged up from 20.20 million tonnes to 30.50 million tonnes at a rate of 5 percent per annum, lower than nation's growth (6.12\%) during 2009-10 to 2018-19 (Table 1). The change in production is attributed mainly due to enhancement in per capita demand for milk and value added milk derived product in domestic markets recently. Population growth, urbanization and income growth, changing in food habits and life style, increasing consumers interest in in high protein diets, increasing awareness and availability of dairy products through organised market chains are important factors for strengthening dairy market in the state as well as in country (NAP 2018).U.P. Dairy sector is on a fast growth track due to elastic demand, economic growth and increasing preference for branded dairy products. Rising consumption coupled with better margins in the value added dairy products are driving growth and higher profitability for dairy players. Similarly per capita per day availability of milk in the state of Uttar Pradesh steadily improved from 283 to 371 grams during discussed period and also remained above nation's average but only lower during 2017-18. The milk production is mainly from three species of mulch animals i.e. Buffalo, cows and goat. Buffalo has domination and her share has been steadily increasing over the last decades. It sprung up from $68.69 \%$ in $2007-08$ to $69.37 \%$ in $2012-13$. After this the share of buffalo to total production began to decline in successive years and reached to $63.92 \%$ during $2018-19$, compared to $69.37 \%$ in $2012-13$ due to increasing share of cross breed cows, non-descriptive cow as well as goat in milk production of state on account of increasing their number and yield per animals (Table 2) As Uttar Pradesh is having good source of water from rivers Ganges and Yamuna with availability of bore well water also at most of the places, green fodder is available almost throughout the year and farmers are willing to increase the milk production. Moreover, there is 
significant Government support for establishment of new projects in the form of various different schemes[19]. Meerut and Lucknow division accounted for about 13\% and 10\% respectively of total milk production of the state followed by Agra, Aligarh and Bareilly division each accounting for 7\%. Regional variation is not uncommon as evident from map (fig. 2). High milk production area in Uttar Pradesh is not contiguous but rather spreads in patches in Western, central and eastern parts amongst either medium or low production regions. The western Uttar Pradesh including Agra, Aligarh, Bulandshahr, Meerut witnessed highest level of milk production owing to their location near country's capital which encouraged dairy farming at commercial level since the beginning of operation flood I. Demand for liquid milk in Delhi Capital Region as well as in various processing units located and mechanization and commercialization of farming system boosted up milk production in this area. About $80 \%$ of farmers mostly from marginal and small group of land holdings, adopted and practising integrated livestock and cropping system. Marketing and processing of dairy products are also well developed and integrated with rural dairy farmers through milk producer's cooperative societies and by private processors through contract dairy farming. The second cluster of high milk production is spread in Bareilly, Badaun and Moradabad which have almost same opportunities and facilities as in first group. Moradabad and Bareilly are important towns inhabited by million of people with greater demand of liquid milk and processed products like Dahi, paneer, ghee, cheese and various milk based drinks. While the south eastern region mainly Allahabad, Azamgarh and Ghazipur district produced milk more than 445,000 tonnes per annum each during 2014-15. Historical factors as well as urban demand especially in Allahabad, Ghazipur and Azamgarh have been important deriving force for high quantum of milk production. Allahabad was selected and dairy hot spot was developed by British Government during 1913 for supplying milk butter to colonial military. The first village dairy co-operative in the country was established in 1917 in a village of Allahabad district, which was followed later on in different parts of the country[19] [20]. The first dairy union i.e. Lucknow Milk Producers Cooperative Union Ltd. was set up during 1935 in the country. Pradeshik Cooperative Dairy Federation Ltd was also set up for technical consultancy in 1862. Government of India and state have also supported the dairy farmers with capital, technology and processing units under different dairy development schemes. U.P. government has plan for refurbishment of Allahabad dairy plants with estimated cost of 12.85 crore INR for packed milk production.

Moreover, the remaining districts in the state lie under category of moderate and low milk production. The moderate category districts are also on the way of progress with the production range of 225,000-445,000 tonnes per annum. Cooperative societies and private processing units are very much active to link the dairy farmers with markets and supply chains. Kanpur, Varanasi, Lucknow, Faizabad and Gorakhpur are important attractive areas of dairy development in this category of milk production. U.P. Government planned to establish some important institutions for dairy farming in eastern Uttar Pradesh[21]. Most of the districts located in the north eastern part along Nepal border (Devipatan Region) and in sBundelkhand region are categorised under low milk producing area of Uttar Pradesh. They have less 227,000 tonnes milk production during same period. The green revolution and mechanization of cropping system discouraged the livestock husbandry on account of reducing the role of male cattle in agriculture as draft animals[22]. Rural urban migration, after releasing of agricultural labour is especially from land less and marginal farmers groups in response to modernization of agriculture is also responsible for low development of dairy farming in these areas. However, the area of low production has been thought as one of the potential dairy development region, if proper planning and dairy development strategies are applied.

Table.1 Share of Uttar Pradesh in total milk production of India

\begin{tabular}{|c|c|c|c|c|c|}
\hline Year & Uttar Pradesh & India & Percent Share & \multicolumn{2}{|c|}{$\begin{array}{c}\text { Per capita Availability ( grams)/ Per } \\
\text { day }\end{array}$} \\
\cline { 4 - 6 } & & & & Uttar Pradesh & India \\
\hline $2009-10$ & 20.203 & 116.400 & 17.36 & 283 & 273 \\
\hline $2010-11$ & 21.031 & 121.800 & 17.27 & 289 & 281 \\
\hline $2011-12$ & 22.556 & 127.900 & 17.64 & 310 & 290 \\
\hline $2012-13$ & 23.333 & 132.400 & 17.62 & 312 & 307 \\
\hline $2013-14$ & 24.194 & 137.700 & 17.57 & 318 & 322 \\
\hline $2014-15$ & 25.198 & 146.300 & 17.22 & 326 & 394 \\
\hline $2018-19$ & 30.51 & 187.700 & 16.25 & 371 & \\
\hline
\end{tabular}


Table 2 Species wise Contribution of Milch Livestock, in Milk Production in Uttar Pradesh during 2007-08 to 2018-19(Figures in Lakh Tonnes)

\begin{tabular}{|c|c|c|c|c|c|c|c|}
\hline Species of Milch Livestock & $\mathbf{2 0 0 7 -}$ & $\mathbf{2 0 1 3 -}$ & $\mathbf{2 0 1 4 -}$ & $\mathbf{2 0 1 5 -}$ & $\mathbf{2 0 1 6 -}$ & $\mathbf{2 0 1 7 -}$ & $\mathbf{2 0 1 8 -}$ \\
& $\mathbf{0 8}$ & $\mathbf{1 4}$ & $\mathbf{1 5}$ & $\mathbf{1 6}$ & $\mathbf{1 7}$ & $\mathbf{1 8}$ & $\mathbf{1 9}$ \\
\hline Cross Breed Cows & 7.72 & 7.26 & 7.30 & 12.32 & 12.25 & 12.35 & 12.44 \\
\hline Non Descriptive Cow & 12.78 & 18.14 & 18.04 & 19.17 & 19.30 & 19.29 & 19.42 \\
\hline Buffalo & 68.69 & 69.46 & 69.55 & 63.67 & 63.77 & 63.73 & 63.97 \\
\hline Goats & 5.80 & 5.16 & 5.10 & 4.83 & 4.73 & 4.61 & 4.48 \\
\hline All & 100 & 100 & 100 & 100 & 100 & 100 & 100 \\
\hline Total Production ( Million Tonnes) & 22.19 & 24.19 & 25.19 & 26.48 & 27.69 & 29.20 & 30.42 \\
\hline
\end{tabular}

*Calculated from data published by Animal Husbandry Department. Govt. India, Uttar Pradesh Lucknow

Table 3 Trends of Milch Livestock in Uttar Pradesh During 2003 to 2019 (Figures in thousand heads)

\begin{tabular}{|l|l|l|l|l|l|l|l|l|l|}
\hline Species & $\mathbf{2 0 0 3}$ & $\mathbf{2 0 0 7}$ & $\begin{array}{l}\text { Change } \\
(\mathbf{\%})\end{array}$ & $\mathbf{2 0 0 7}$ & $\mathbf{2 0 1 2}$ & $\begin{array}{l}\text { Change } \\
(\mathbf{\%})\end{array}$ & $\mathbf{2 0 1 2}$ & $\mathbf{2 0 1 9}$ & $\begin{array}{l}\text { Change } \\
(\mathbf{\%})\end{array}$ \\
\hline CB Cows & 642 & 791 & 5.38 & 791 & 1660 & 109.80 & 1660 & 2951 & 77.70 \\
\hline ND Cows & 4901 & 5537 & 3.10 & 5537 & 6595 & 19.12 & 6595 & 5588 & -0.07 \\
\hline Buffalo & 10379 & 10565 & 0.44 & 10565 & 13950 & 35.04 & 13950 & 14691 & 5.31 \\
\hline Goat & $5694^{*}$ & $6508^{*}$ & 14.29 & 6508 & 6907 & 6.13 & 6907 & 6919 & 0.17 \\
\hline Total & 21516 & 23401 & 8.76 & 23401 & 29112 & 24.40 & 29112 & 30149 & 3.56 \\
\hline
\end{tabular}

- $\quad$ Refers $44 \%$ of total population as milch goat

- Milch Livestock includes females in milk and dry categories.

Source: $19^{\text {th }}$ and $20^{\text {th }}$ Livestock Census, $2012 \& 2019$, Government of India, Ministry of Agriculture, Department of Livestock Husbandry, Dairying and Fisheries, New Delhi

Table 3 shows that total milch livestock increased $8.76 \%$ during 2003-2007, $24.40 \%$ during 2007-2012 and $3.56 \%$ during 2012-2019. Table 3 also shows that cross breed cows increased by $5.38 \%$, indigenous cows increased by $3.10 \%$ while buffalo increased by $0.44 \%$ and Goat has increased by $14.29 \%$ during $2003-2007$. Cross breed cows increased by $109.80 \%$, indigenous cows increased by $19.12 \%$ while buffalo increased by $35.04 \%$ and Goat has increased by $6.13 \%$ during $2007-2012$. Cross breed cows increased by $77.70 \%$, indigenous cows declined by $-0.07 \%$ while buffalo increased by $5.31 \%$ and Goat has increased by $0.17 \%$ during $2012-2019$.

Table 4 depicts that there are 52.03 bovine livestock and 47.88 million female bovine while the production of milk from them is 30.50 million tonnes. The yield for cross breed cows is 7.35 litres per day while yield for non descriptive cows is 3.06 litres per day, on the other hand the yield for buffalo is 4.53 litres per day and for goat it is 0.78 litres per day. There are 6,835 Co-operative Societies, 520 Bulk Milk Coolers, 912,000 litres processing capacity and 3,57,000 litres per day production of milk in India. There are 234 processing plants and their capacity 22569 trillion litres per day. There are 334,0000 households in 97,814 villages out of which 67,291 are dairy potential villages.

Table 4 Dairy Farming and Marketing: General Profile 2018-19

\begin{tabular}{|c|c|c|c|c|c|}
\hline Particulars & Unit & Value/ Number & - & - & - \\
\hline Bovine Livestock & Million heads ( 2019) & 52.03 & - & - & - \\
\hline Female Bovine & Do & 47.88 & - & - & - \\
\hline Milk Production & Million tonnes( 2018-19) & 30.50 & - & - & - \\
\hline $\begin{array}{l}\text { Yield (lts per } \\
\text { animal) } 2018-19\end{array}$ & $\begin{array}{c}7.35 \text { litres Cross Breed } \\
\text { Cow }\end{array}$ & $\begin{array}{c}3.06 \text { litres, Non } \\
\text { Descriptive Cows }\end{array}$ & $\begin{array}{l}4.53 \text { litres } \\
\text { Buffalo }\end{array}$ & $\begin{array}{l}\text { Goat } 0.78 \\
\text { litres }\end{array}$ & \\
\hline $\begin{array}{l}\text { Co-operative } \\
\text { Societies }\end{array}$ & - & 6,835 & $\begin{array}{c}\text { 520 Bulk } \\
\text { Milk } \\
\text { Coolers }\end{array}$ & $\begin{array}{l}\text { 912,000 } \\
\text { litres } \\
\text { capacity/ } \\
\text { day }\end{array}$ & $\begin{array}{c}3,57,000 \\
\text { litres/ day } \\
\text { of milk } \\
\text { production }\end{array}$ \\
\hline Processing Plants & - & 234 & $\begin{array}{l}\text { Capacity. } 22 \\
569 \text { Trillion } \\
\text { litres per day }\end{array}$ & - & - \\
\hline Total House Holds & Lakh & 334 & - & - & - \\
\hline $\begin{array}{ll}\text { Total No. of } \\
\text { Villages }\end{array}$ & - & 97814 & - & - & - \\
\hline $\begin{array}{ll}\text { Dairy } & \text { Potential } \\
\text { Villages } & \\
\end{array}$ & - & 67291 & - & - & - \\
\hline
\end{tabular}

Source: Ministry of Agriculture and Farmer's Welfare, Govt. of India, 2018 


\section{Drivers of Dairy Development}

The state of Uttar Pradesh has been always one of the potential region of dairy development in India. Being a biggest state not only in area and population but in livestock number especially in milch animals, she achieved the level of 30.50 million tonnes of milk production during 2018-19 securing 19\% of country's production. Historical initiatives through government policies and institution establishment during past decades during pre and post-independence period were one of the most effective drivers of dairy development in Uttar Pradesh. Selection of Allahabad for setting up first dairy centres by British Government for supply of milk and butter to colonial army in 1913, first milk producers cooperative society in 1889, establishment of first dairy producers union called as Lucknow Milk Producers Co-operative Union Ltd in 1935, establishment of National Dairy Development Board in 1965 and Pradeshik Cooperative Dairy Federation Ltd. as a technical consultancy in 1962 have been a latent source of powers for dairy farming improvement in the state[23]. The improvement in milk production is the result of increasing urban population, improvement in disposable income both in urban and rural areas, food habits change, improvement in life style, increasing awareness for nutrition rich food and largest number of vegetarian population in the recent decades [24]. It is also due to having largest number female bovine including cows and buffalo (18\%), and largest number of vegetarian population who require dairy products for meeting their nutrition demand. As on 2017-18, U.P dairy industry is equipped with 6835 milk cooperative societies, 520 Bulk milk cooler units with capacity of 9,12,000 litres [25].

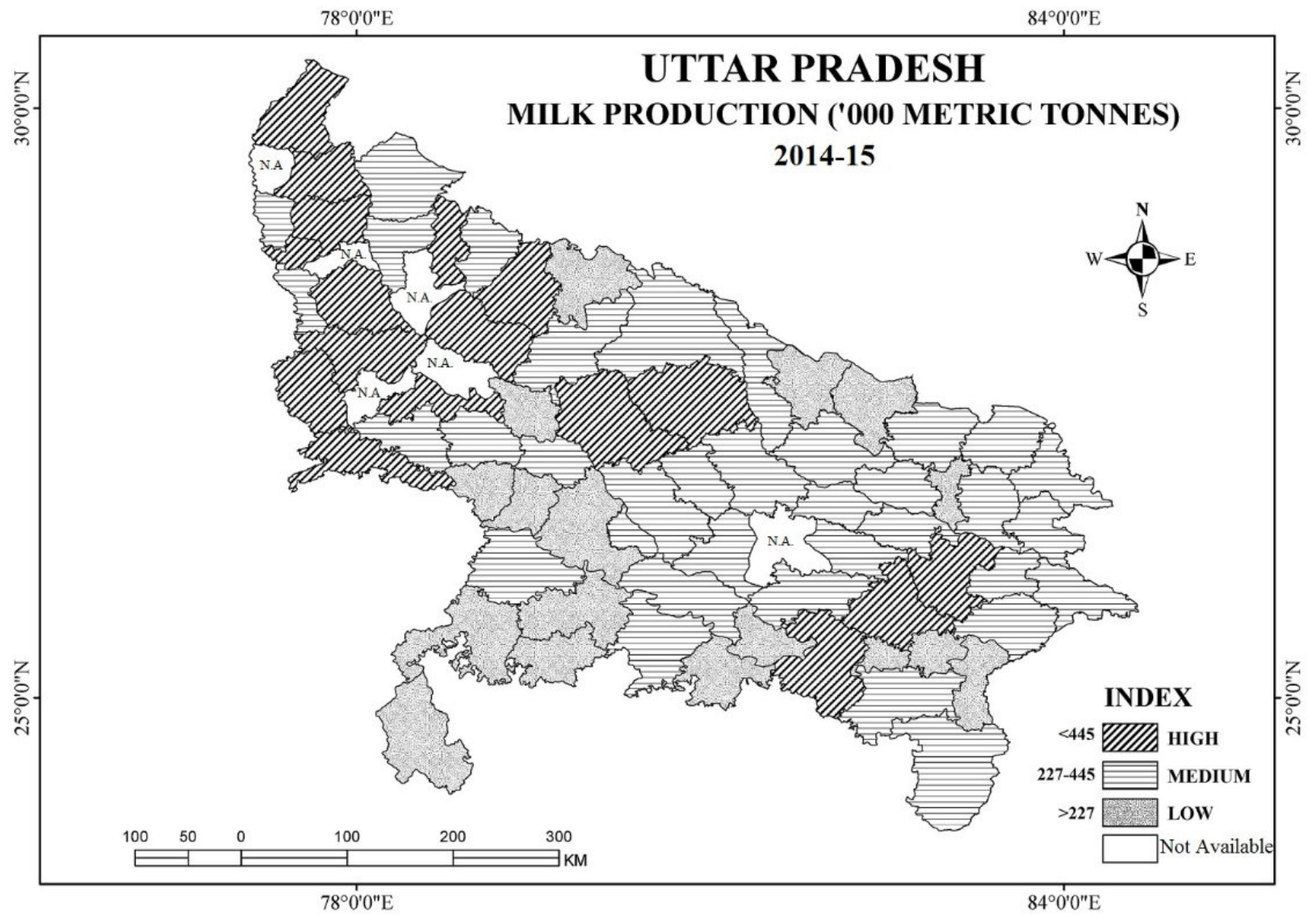

Fig.2 Production of Milk in Uttar Pradsh

Moreover, the liberalization of agricultural trade after 1994, appeared another important driving force for breakthrough in dairy farming and industries in the state. Capital investment, both by private and public sectors including cooperatives, enhanced the markets for raw milk and processed products. Intensity and degree of integration between cropping and livestock rearing especially dairy farming improved production per head as well as per livestock on account of state support and technological up gradation. Dairy value chain including milk processors and other stakeholders in the chain are key factors to develop medium-scale farmer driven dairy farms. Dairy sector in UP is on a fast growth track due to elastic demand, economic b growth and increasing preference for branded dairy products. Rising consumption coupled with better margins in the value added dairy products are driving are driving growth and higher profitability for dairy players. As per Industry estimates, the share of value added dairy products in the milk and milk derivative segments is growing currently in UP at around $25 \%$ every year and is expected to grow at the same rate until 2020[26]. The state has also good source of 
water from rivers like Ganga, Yamuna and Ghagra and also extensive network of tube well at most places and availability of green and dry fodder from existing cropping system almost throughout the year, the farmers are continuously moving ahead in dairy farming development and expected to move in future.

Moreover, recently, Uttar Pradesh Government has been encouraging the dairy sector in the state through various schemes and invitation to private sectors in process of value addition and creation of demand for milk and milk products. Many private players are establishing milk processing plants in UP. Few existing players like VRS Dairy and Gopaljee are expanding their processing capacity. Major Private Players are mainly doing investments in expanding their milk procurement infrastructure or diversifying into new product categories like flavoured milk, curd, UHT milk etc. Cooperatives like AMUL are also expanding in a big way in UP. Some of the recent dairy sector developments in the state included Banaskantha District Co-operative Milk Producer's Union Ltd (Banas Dairy), a member union of the Gujarat Cooperative Milk Marketing Federation (GCMMF) that markets AMUL brand is establishing two plants of 0.5 million liters per day each in Lucknow and Kanpur in Uttar Pradesh. Banas dairy is also planning to establish a processing plant in Varanasi of 500,000 liters per day processing capacity expandable to 1 million liters per day. ITC is planning to establish a milk processing unit in Uttar Pradesh in coming years. VRS Foods has invested around INR 3 billion for expansion of its dairy unit in Hardoi district in central UP from 350,000 liters per day to 1million liters per day of milk. Large players like VRS, Bhole Baba Dairy, established for quite some long time with capacities ranging from 2.5-3.5 million liters per day, have started with manufacturing of by-products like casein[27]. Besides, New Green Field plant and refurbishment of old dairy plants within the state have been also introduced with a value of 1067.30 crore INR at Varanasi, Meerut, Lucknow, Bareilly, Gorakhpur, Firozabad Moradabad, Kannuj and Faizabad to supply fodder, feed grains and train the farmers for scientific dairy farming and awareness about various programmes.

\section{Marketing and Processing of Milk and Milk Products}

Marketing and processing of milk and milk products refer to a mechanism of creating demand of milk through the process of producing, packaging, treating and warehousing of milk products. Milk processing techniques utilized by market players involve pasteurization, cooling and conversion into concentrated high value added products. There are several key players which presently functioning more significantly for leading wide market growth and dominating the high value of market share during short span of time while developing quality of products, decreasing the prices of products, doing effective packaging, producing hygienic products and develop the productivity of products. Such private players include Parag milk food Ltd, Mother Dairy Food Fruit Vegetable Private Ltd, Amul, VRS dairy, SMS Food, Gopal ji Dairy, and several others. Banās dairy, one of the biggest dairies in Asia in the cooperative sector set up its shops in the state for procuring, processing and marketing the products. It is largest member union of Gujarat Co-operative Milk Marketing Federation which sell milk under AMUL brands. It has two plants of 5 lakh litres per day capacity each in Kanpur and Lucknow catering to a sizeable number of small dairy farmers in central U.P. district[28]. Namaste India with capacity of 9,00000 litres per day processing was established in 2013. U.P. had 25 million litres per day milk processing capacity during 2013-14, out of which $90 \%$ is shared by private sector. Table 5 reveals that 693 trillion $\mathrm{kg} / \mathrm{day}$ was procured by both cooperatives and private players during 2015-16. Similarly the state had chilling infrastructural capacity $15526 \mathrm{TKg}$ / day and 234 dairy plants with processing 22569 trillion litres per day during same period. Private players including small village traditional units and big companies contributed largest share with 61 percent in processing of dairy products. It is followed by Co-operative societies and Government establishment with 36 and 02 percent share respectively. The state govt. has been continuously making endeavour to encourage and improve dairy economy through strengthen linkage among production, value addition and distribution to targeted consumers. Table 6 highlights the various expected cost of setting up various plants in U.P. by Uttar Pradesh government and products to be manufactured in them. It shows that expected cost of Jhansi plant is INR 14.87 Crores and packed milk and curd will be manufactured in it. Noida Dairy plant will produce packed milk and cost of this plant will be 22.83 crores. The expected cost of Aligarh Diary plant is INR 45.92 crores and it will produce packed milk, curd, lassi. Allahabad Dairy plant will have the cost of INR 12.85 crores and packed milk will be produced in this plant while expected total cost of all these plants will INNR 96.47 cores.

The processing or manufacturing units perform dual functions of value addition and distribution of dairy products simultaneously. Parag, Amul, Gopal ji , Mother Dairy and several others are very active in markets through supply of even packed liquid milk. Recently, a large number of new plants are proposed by the government to establish at different places of the Uttar Pradesh as shown in table 7. Gorakhpur, Bareilly, Moradabad, Meerut, Aligarh, Kannauj, Kanpur, Allahabad, Varansi, Faizabad and Firozabad are selected taking into consideration of regional imbalances improving in dairy development of the state. Some old dairy plants are also selected for rehabilitation as indicated in table 6. Refurbishment of dairy plant of Aligarh, Noida, Jhansi and Allahabad are also proposed for betterment of dairy processing infrastructure facilities in the concerned areas. Besides, some schemes are also introduced at district level with a view to strengthen, reconstruction of dairy 
federations or societies to provide financial support to milk unions, societies, through working capital , administrative grant, propulsion charges, head load grant and other requirements are provided for operation of milk cooperative societies. New agricultural marketing policies and fund for agricultural infrastructure and establishment of private processing units, collection centres and reducing length of market channel for an efficient marketing of milk and milk derived products in the state are some excellent strategic measures and step for maximization of producers 'benefits and rational consumer's price.

Marketing behaviour of dairy products in the state of Uttar Pradesh is of complex nature like that of developing countries of world in general and in India particular. The important components or players, involved in the process of movement of raw milk and processed dairy products from producers to final consumers, are producers, village traders, and co-operative societies, contractor, processing units and transporter as well as ware houses / wholesalers. The products of transaction include raw milk, packed milk, curd, yogurt, paneer, khoya, SMS, white butter, ghee, ice cream, chach, UHT etc.

The study of dairy value chain or market channel in the state reveals that approximately 30 percent of marketable surplus of milk routed through organised sectors including cooperatives, government and private agencies[29]. Remaining 70 percent is sold through unorganised traditional system, Out of marketable surplus ( $\sim 50 \%$ of milk production) $67 \%$ of milk in the state is sold as liquid milk, $10 \%$ as traditional Indian sweets, $9 \%$ as milk powder, $6 \%$ as ghee and rest as curd, paneer, milk drinks and dairy whitener .

Direct channel is the most common in which producer sellers get direct contact with consumers as households, tea stall, and sweet makers in both rural and urban areas. Urban dairy centres follow almost 100 percent this channel. Direct channel is beneficial for both producers and consumers, the farmers get rather higher price and latter pay low due to reduction of charge of intermediaries between them. Contract method is also prevailed through which local unorganised as well as organised private players purchased raw milk in the area under discussion. These contractors collect milk from individual farmers and supply it to the plants. The logistics and collection cost is borne by the contractor. But companies are facing challenges in terms of quality of milk while purchasing milk from contractors. Hence many companies are investing in building their own procurement infrastructure. Contract dairy marketing is thought as beneficial for smallholder's dairy farmers engage in contract marketing for the reasons i.e. access to markets and market information, access to technical assistance, access to credit and inputs, higher income and status and reduction of market and production risk. It is further confirmed that if producers engage in contract marketing, they will get sound returns which improve their livelihoods and incomes[30]. But some of scholars look it as an exploitation system for producers[31]. Generally the payment to the dairy farmers for their sold milk is rather low and long delayed. The processing companies are also having doubt for quality when purchased milk from contractors. The contract marketing is a means of exploitation of farmers by agribusinesses/contractors due to unequal power relations[32]. He also examined the demerits of contract marketing for producers such as, loss of autonomy / flexibility, lack of transparency (particularly in price determination), contractors might renege on contract, risk of indebtedness and adverse gender effect. Moreover, it controls a lion share of marketed surplus of dairy and dairy production the state of Uttar Pradesh.

Private processing units is another important market players which purchased raw milk directly from farmers or village contractors and sell back processed product i.e. Packed milk,dahi, curd, so on through distributors/ retailor to the consumers both in urban and rural areas. They control about 90 percent of total processed products in the state. The share of processed dairy products sale has been increasing even among rural consumers due quality control and hygienic in nature as compared to unorganised products.

Co-operative milk producer's societies played pivotal roles in production, processing and marketing of dairy products. The marketable surplus is pooled at collection centres in rural areas and sent to their cooling and processing centres. Processed products are marketed to consumers through wholesalers and retailers. AMUL, PARAG, Mother Dairy are well known brand which products are largely in north Indian states especially in U.P. A summary of market channels of dairy and dairy products in Uttar Pradesh is illustrated in figure 3 . The breakup of various forms of market chains are given below.

1) Producer - - > Consumer

2) Producer - - >Small Milk Trader - - >Consumer

3) Producer - - >SMall Milk Trader - - > Retailer- - >COnsumer

4) Producer- - $>$ Dairy Cooperative - - >Consumer

5) Producer - - > Dairy Cooperative - - > Retailer- - >COnsumer

6) Producer --> Milk Processing Units-- $>$ Local Market-- $>$ Consumer

7) Producer-- > Contractor -- > Processor -- > Whole saler -- > Retailer -- > Consumer 


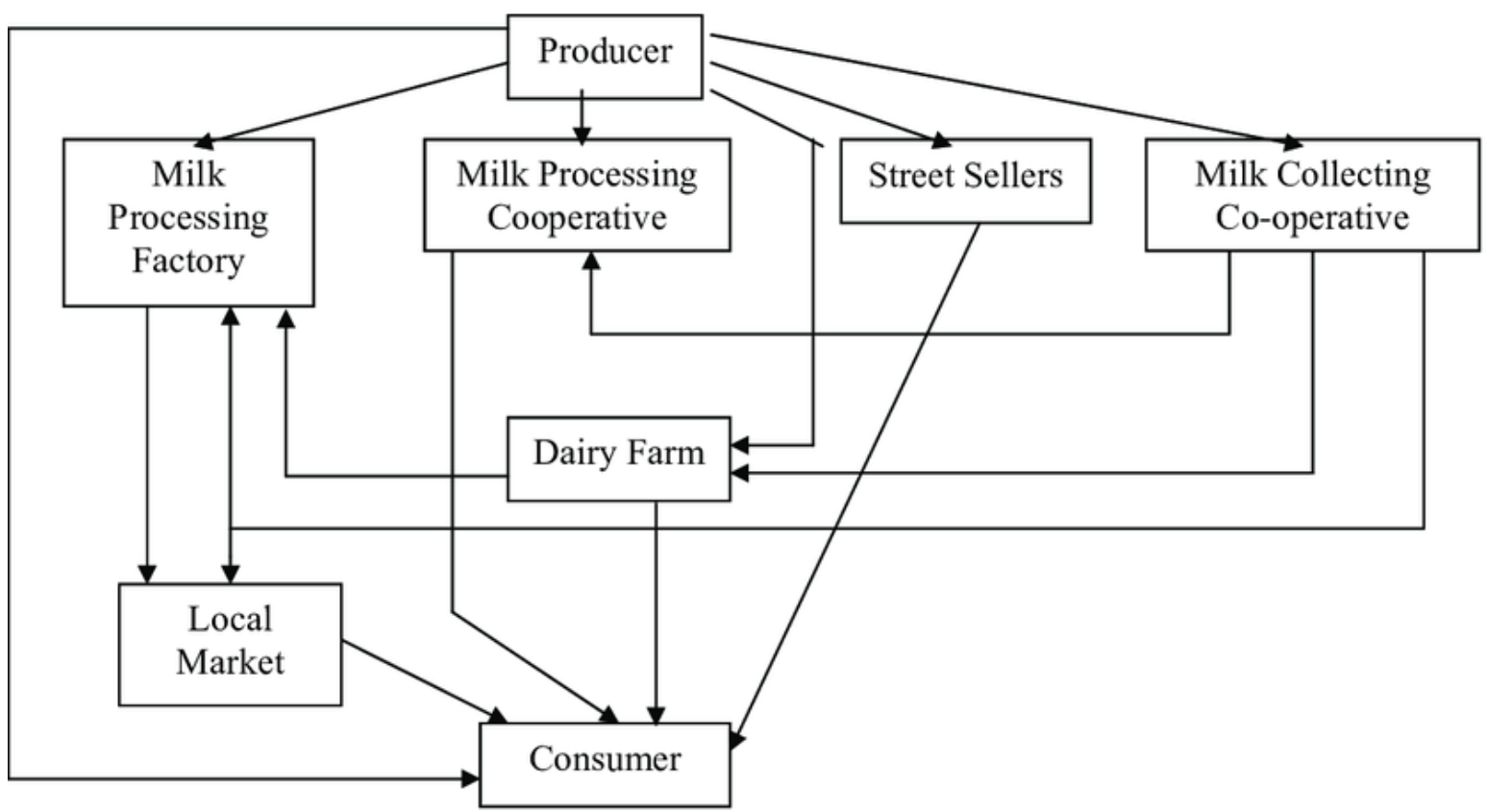

Fig. 3 Diagram reveals the flow of milk and processed products

Table: 5 Profile of Dairy Processing Capacity in Uttar Pradesh 2015-16

\begin{tabular}{|l|l|}
\hline Items & Volume/ weight \\
\hline Milk Procurement & 693 Trillion $\mathrm{kg} /$ day \\
\hline Co-operatives & 326 Trillion Kg/day \\
\hline Private Producers Company & 368 Trillion Kg/day \\
\hline Chilling Infrastructure Capacity & 1556 Trillion Kg/day \\
\hline Cooperative & 935 Trillion Kg/day \\
\hline Private Producer Company & 621 Trillion Kg/day \\
\hline Village Covered by Dairy Processors & 29.35 thousand \\
\hline Co-operatives & 27.25 Thousand \\
\hline Private Producers Company & 2.15 Thousand \\
\hline No. of Dairy Plants & 234 (Capi. 22569 Trillion litres per day) \\
\hline Co-operatives & 18 \\
\hline Private Producer Company & 216 \\
\hline Processing share & 100 percent \\
\hline Private Companies & 61 percent \\
\hline Cooperatives & 36 Percent \\
\hline Government & 03 Percent \\
\hline
\end{tabular}

Source: National Action Plan for Dairy Development, Mission 2022, Ministry of Agriculture and Farmers Welfare, Govt. of India, January, 2018

Table 6 Programmes introduced by U.P. Government to Add Value to Raw Milk in Uttar Pradesh

\begin{tabular}{|l|l|l|l|}
\hline S.N. & Project Name & $\begin{array}{l}\text { Expected Cost (INR } \\
\text { Cr.) }\end{array}$ & $\begin{array}{l}\text { Name of Manufactured } \\
\text { Products }\end{array}$ \\
\hline 1 & Refurbishment of Jhansi Dairy Plant & 14.87 & Packed Milk \& curd \\
\hline 2 & Refurbishment of Noida Dairy Plant & 22.83 & Packed Milk \\
\hline 3 & Refurbishment of Aligarh Dairy Plant & 45.92 & Packed Milk, Curd, Lassi \\
\hline 4 & $\begin{array}{l}\text { Refurbishment of Allahabad Dairy } \\
\text { Plant }\end{array}$ & 12.85 & Packed Milk \\
\hline & Total Value (INR Cr) & 96.47 & \\
\hline
\end{tabular}

Source: U.P. Powering New India, Investor Summit 2018 
Table 7. Proposal for New Green Field Plants and Refurbishment of Old Dairy Plants in Uttar Pradesh

\begin{tabular}{|c|c|c|c|}
\hline S.N. & Project Name & $\begin{array}{l}\text { Expected } \\
\text { Cost } \\
\text { (INR Cr) }\end{array}$ & $\begin{array}{l}\text { Name of Manufactured } \\
\text { Products }\end{array}$ \\
\hline 1 & Varansi Plant with capacity 4 lakh litres production & 152.49 & Packed milk, paneer, SMP \\
\hline 2 & $\begin{array}{l}\text { Meerut Plant along with UHT and with capacity of } 4 \text { lakh } \\
\text { litres production }\end{array}$ & 172.56 & $\begin{array}{l}\text { Packed milk, Ghee, Cream, } \\
\text { Curd, Chach,SMP }\end{array}$ \\
\hline 3 & Lucknow Plant with capacity of 3 lakh litres production & 117.43 & $\begin{array}{l}\text { Packed milk, paneer, yoghurt, } \\
\text { Khoya }\end{array}$ \\
\hline 4 & Bareilly Plant with capacity of 01 lakh litres production & 76.25 & $\begin{array}{l}\text { Packed Milk, Yoghurt, Ice } \\
\text { Cream }\end{array}$ \\
\hline 5 & $\begin{array}{llllll}\begin{array}{l}\text { Gorakhpur } \\
\text { production }\end{array} & \text { Plant with capacity of } 01 \text { lakh litres } \\
\end{array}$ & 60.09 & Packed Milk \\
\hline 6 & $\begin{array}{l}\text { Firozabad Plant with capacity of } 01 \text { lakh litres } \\
\text { production }\end{array}$ & 60.88 & Packed Milk, Khoya \\
\hline 7 & $\begin{array}{l}\text { Moradabad Plant with capacity of } 01 \text { lakh litres } \\
\text { production }\end{array}$ & 61.29 & Packed Milk, Yogurt, Ice Cream \\
\hline 8 & $\begin{array}{l}\text { Kannauj Plant along with UHT and with capacity of } 01 \\
\text { lakh litres production }\end{array}$ & 148.52 & $\begin{array}{l}\text { Cow Milk, Khoya, Ghee, Chena, } \\
\text { White Butter, UHT }\end{array}$ \\
\hline 9 & $\begin{array}{l}\text { Faizabad Plant along with UHT and with capacity of } \\
0,50 \text { lakh litres production }\end{array}$ & 65.04 & Packed Milk, Fino Packed Milk \\
\hline 10 & $\begin{array}{l}\text { Kanpur Plant with capacity of } 01 \text { Lakh litres production } \\
\text { and } 20 \text { tonnes of powdwer plant }\end{array}$ & 152.75 & $\begin{array}{l}\text { Packed Milk, Ghee, Paneer, } \\
\text { White Butter, SMP }\end{array}$ \\
\hline
\end{tabular}

Source: U.P. Powering New India, Investor Summit 2018

\section{Comparative Study of Bulandshahr and Balrampur District}

The dairy development in term of production, processing and distribution in Uttar Pradesh is appreciable level and achieved first rank in the country with production of 30 million tonnes in 2018-19. The milk distribution map (fig 2) reflected contrasting regional variation with highest production of 1285 thousand tonnes in Bulandshahr and lowest 107 thousand tonnes in Shravasti district of the state during 2015-16. Two districts one each from high and low developed as aforesaid are selected to understand the differences in development of dairy economy in eastern and western Uttar Pradesh. Brief components of dairy development in these districts are given below in table 8 .

Table 8 Comparative Profile of Dairy Development in Bulandshahr and Balrampur District, Uttar Pradesh

\begin{tabular}{|c|c|c|c|}
\hline S.N. & Components/ Features & Bulandshahr & Balrampur \\
\hline 1 & Milch Livestock & 644767 & 175966 \\
\hline 2 & Milk Production* & 1285 thousand tonnes & 156 thousand tonnes \\
\hline 3 & $\%$ age of dairy farmers to total farmers & 80 & 30 \\
\hline 4 & Herd Size ( Stock Size) & 05 & 03 \\
\hline 5 & $\%$ age of Marketable Surplus & 60 & 70 \\
\hline 6 & $\begin{array}{l}\text { Share of organised sector in marketing of } \\
\text { milk and milk derived Products }\end{array}$ & 70 & 40 \\
\hline 7 & Per Capita Milk Available & $1006 \mathrm{~g} /$ day & $198 \mathrm{~g} /$ day \\
\hline 8 & Share of Direct sale of Milk by Producers & 54 & 80 \\
\hline 9 & $\begin{array}{c}\text { Share of Cooperative Societies in sale of } \\
\text { marketable Surplus }\end{array}$ & 35 & 05 \\
\hline 10 & $\begin{array}{c}\text { Share of Village/ contract trader in sale of } \\
\text { marketable Surplus }\end{array}$ & 10 & 15 \\
\hline 11 & Milch Animal and Cropped Area Index & $\begin{array}{ll}127.42 & \text { livestock per } 100 \\
\text { hectares }\end{array}$ & $\begin{array}{c}47.69 \begin{array}{l}\text { livestock per } 100 \\
\text { hectares }\end{array} \\
\end{array}$ \\
\hline 12 & Milch Animal and Population Index & $\begin{array}{l}184.26 \text { Livestock per } \\
\text { thousand population }\end{array}$ & $\begin{array}{l}81.90 \text { Livestock per } \\
\text { thousand population }\end{array}$ \\
\hline
\end{tabular}

- $\quad$ Production in 2015-16

- Source: Field Survey, Singh, R. et. al. 2018, Supply and Utilization Pattern of Milk in Bulandshahr District, India, International Journal Current Microbiology and Applied Sciences, Issue.7 pp.2615-20 
The features mentioned in the table clearly indicate that these two districts stand at very critical extreme low and high dairy development. Bulandshahr, being located in NCR area, achieved the highest score of milk production in the state with 1285 thousand tonnes as compared to Balrampur with 156 thousand tonnes during 2015-16. Herds or stock size, on an average, is 05 livestock and milch animals per thousand populations and per hundred hectares cropped area are 184.26 and 127.42 respectively in Bulandshahr district, whereas the same features are 03, 81.90 and 47.69 in Balrampur district. The variation in degree of development has impacted the process and mechanism of distribution and marketing of dairy products. The share of organised sector including cooperative societies, private processing companies and government controlled dairy industries is about 70 percent in marketing of milk and milk derived product marketable surplus, while the share of direct sale between producers and consumers, cooperatives and contractors/ intermediaries are 54, 35 and 10 percent of total marketable surplus transacted in former district. Contrary to it, latter area reflected 40, 80, 5 and 15 respectively (Table 8 ). There is a sharp gap between per capita availability of milk in these districts as 1006 grams per day and 198 grams/ day respectively. Moreover, the state of Uttar Pradesh with highest production in the country, inter districts as well as intra district imbalances in dairy farming development is very critical and serious challenge for government, policy makers as well as farmers in backward regions, especially eastern Uttar Pradesh.

\section{Challenges and Opportunities in Future}

Uttar Pradesh, though, is leading state in number of milch livestock and milk production in the country but it is suffering from various difficulties and facing different issues and challenges. Low yield per livestock, small size of stock, domination of small and marginal farmers, small size of marketable surplus and traditional forms of dairy farming are some of important problems and resistance in development of dairy farming, processing and marketing of dairy products in the state. Farmers access to organised market, processing of milk \& Value Added Products and availability of quality milk \& milk products to consumers are another issues faced by Indian dairy sector in general and Uttar Pradesh in particular. Besides, age old infrastructure with obsolete technology, lack of organised credit facilities, lack of manufacturing and processing facilities for value added products especially in eastern Uttar Pradesh, lack of efficient chilling infrastructure at village level, lack of efficient cold chain distribution and integration of poor producers to national and international supply chains are critical challenges identified by NAP Dairy Development plan 2022 (NAP 2018), Regional imbalance is another challenge before state how to develop backward districts in dairy farming.

Moreover, dairy sector of agricultural economy in U.P has very promising and potential future. The comparative study of districts, revealed high level of potential existed in the least developed district like Balrampur for multi-dimensional opportunities for dairy farming development and its allied activities when it is developed at least at the level of developed area. Development of fodder production farms, outlet establishment for supply of concentrates, production and supply of feed grains, new development of credit and insurance institutes and investment in local dairy processing industries are some valuable opportunities in dairy farm production (Investor Summit 2018). The plan of doubling farmers income and strengthen the level of economic self-reliance in rural area could be achieved successfully.

\section{Conclusions}

Marketing of dairy products is the reflection of demand and supply of milk and its derived products. The value addition and cold chain development in distribution system strengthen the production of raw milk at producers end and enriching food nutrition with reasonable price and qualitative products at last destination of consumers. The involvement of private companies, both national and international, along with co-operative dairy societies brought a dramatic growth in dairy sector in the country but still the export of dairy products is very insignificant. World producers and manufacturers are very much enthusiastic to catch Indian markets. The Indian dairy production quantum is more sufficient to cater on local demand of 1.30 billion population and even more production could be made to export to international markets due to high competitive advantage on account of low labour and production cost.

The marketing and distribution of milk and its derived products are controlled by unorganised sector including producer sellers, village traders, and local producers as sweet makers, tea stalls and household consumers. Approximately, only one third of marketable surplus moves through organised sector including cooperatives, private and public processing units. The share of organised sector should be enhanced to highest possible level in view to develop efficient marketing channels and distribute qualitative, hygienic and low price products. Packaging, branding and processing the raw milk into value added products like curd, yogurt, butter, ice cream, paneer, skimmed powder etc are the key attributes of creating demand and development of dairy farming at grassroots level. Dairy sector in Uttar Pradesh is on a fast growth track due to elastic demand, economic growth and increasing preference for branded dairy products. Rising consumption coupled with better margins in the value added dairy products are driving growth and higher profitability for dairy players. Regional 
variation is common phenomena. Western and central parts of the state generally recorded appreciable status in dairy development while the eastern part witnessed backwardness. This fact is verified and tested on the basis of comparative study of Bulandshahr and Balrampur districts. Bulandshahr achieved great success in production, processing and marketing and generation of employment and income as compared to Balrampur which experienced very bad performance. The area needs special attentions of policy makers and government for development of dairy sector in response to area, people and species of animals in the state. Cold chains linkage with refrigerated transport and storage are urgent demand for bringing a breakthrough in milk production and for improving farmer's income and developing self-reliance in income, employment and food security. Dairy farm production systems are treasure of tremendous opportunities for farmers and area development. Development of fodder production farms, outlet establishment for supply of concentrates, production and supply of feed grains, new development of credit and insurance institutes and investment in local dairy processing industries are some valuable opportunities in dairy farm production (Investor Summit 2018). The plan of doubling farmers income and strengthen the level of economic self-reliance in rural area could be achieved successfully.

Acknowledgement: We are highly grateful to MHRD (IMPRESS SCHEME) under Indian Council of Social Science Research, New Delhi, for providing financial support to prepare this research paper.

\section{References}

[1] National Commission on Agriculture ( 1976) XII Report, Govt. of India, New Delhi

[2] Acharya, S.S. \& Agrawal, N.L. (2004) Agricultural Marketing in India, Oxford and IBH Publishing Co. Ltd. New Delhi

[3] Research \& market (2019) The Dairy \& Milk Processing Market in India, 2018-2019 \& 2023 ResearchAndMarkets.com

[4] Verwer, C.C.B. (2013) Investigating Marketing Opportunities for Dairy Products from Dam Rearing System, Louis Bolk Institute, www.louisbolk.org

[5] De Chernatony, L. \&Harris, F. (2000). Added value: its nature, roles and sustainability. EuropeanJournal of Marketing 34(1/2)

[6]Buhr, B. L. (2004). Case Studies of Direct Marketing Value-Added Pork Products in a Commodity Market. Review of Agricultural Economics 26(2): 266-279

[7] Cuthbert, R. H. (2008).Strategic Planning - Niche Marketing in the Agriculture Industry. (Ed C. a. M. D. A. P. R. Network). Department of Rural Economy, University Alberta, Canada

[8] Herath, H. M. U. N. \&De Silva, S. (2011). Strategies for Competitive Tea Marketing. Tropical Agricultural Research 22(3): 251-262.

[9] NAP ( 2018) National Action Plan for Dairy Development, Vision 2022, DAHDF, Mo AFW, New Delhi

[10] Research \& market (2019) ibid.

[11] Whithead, R. (2019) Can India Double Dairy Farmers Income in Three Years? , Dairy, reporter.com , 17 $7^{\text {th }}$ February (2019).

[12] Imran, A., Zadeh, M.N. and Dube, L.R( 2011) Dairy Marketing Strategies in the Context of Globalization, Indian Journal of Trade and Finance, Vol.2, No. 2, pp.1-11.

[13] NAP (2018) ibid.

[14] Dublin (2018) Uttar Pradesh Dairy Market Size, Growth Price, Distribution Analysis and Forecast to 2023, Business wire, Research and Markets. Com, press@researchandmarket.com

[15] Whitehaed, R.( 2019) ibid.

[16] ICFA(2019) Indian Dairy Products Market, www.icfa.org.in

[17] NITI AAYOG ( 2018) Demand \& Supply ProjectionTowards 2033, Crops, Livestock, Fisheries, and Agricultural Inputs , The Working Group Report, NITI AAYOG, Govt. of India, New Delhi

[18] FASAR ( 2016) Dairy Sector in India: Opportunities in Key States and Products, Yes Bank, Netherlands Embassy, New Delhi

[19] NAP ( 2018) ibid.

[20] FASAR ( 2016 ) Dairy Sector in India: Opportunities in Key States and Products, Yes Bank, Netherlands Embassy, New Delhi, ibid.

[21] U.P. Investor Summit (2018) U.P Powering India, Dairy Nourishing, , 21-25 February, 2018, Lucknow, www. Upinvestorsummit.com

[22] Singh, R.S. and Shukla, N.S. ( 2017)Assessment of Status of Dairying and Potential to Improve Socio Economic Status of Milk Producers in Eastern Uttar Pradesh, Study Sponsored by Ministry of Agriculture and Farmers Welfare Government of India, New Delhi Agro-Economic Research Centre University of AllahabadAllahabad-211002

[23] U.P. Investor Summit (2018) U.P Powering India, Dairy Nourishing, , 21-25 February, 2018, Lucknow, 
www. Upinvestorsummit.com, ibid.

[24] Tabrez, Z. \& Khan, N. (2013) Level of Mechanization of Agriculture in Gonda District: A Geographical Study, BhoogolDigdarshan (Earth Surface Review) Vol.4, No..2, pp.1-7.

[25] Singh, P.S. Shukla, R.S. (2017) ibid

[26] NAP (2018) ibid

[27] U.P. Investor Summit (2018) U.P Powering India, Dairy Nourishing, , 21-25 February, 2018, Lucknow, www. Upinvestorsummit.com, ibid.

[28] FASAR(2016) Dairy Sector in India: Opportunities in Key States and Products, Yes Bank, Netherlands Embassy, New Delhi, ibid.

[29] FASAR(2016) Dairy Sector in India: Opportunities in Key States and Products, Yes Bank, Netherlands Embassy, New Delhi, ibid.

[30] Bijman, J. (2008). Contract Farming in Developing Countries: An Overview. Working Paper. Retrieved March 17, 2009, from www.mst.wur.nl

[31] Swinnen, J., \&Maertens, M. (2006).Globalization, Privatization, and Vertical Coordination in Food Value Chains in Developing and Transition Countries. Plenary 76 paper prepared for presentation at the International Association of Agricultural Economists Conference, Gold Coast, Australia

[32] Singh, S. (2002)."Contracting Out Solutions: Political Economy of Contract Farming in the Indian Punjab. "World Development Vol.30, No.9, pp. 1621-1638. 